\title{
Mathematics Teachers Standing on the Utilization of Digital Resources in Kathmandu, Nepal
}

\author{
Dirgha Raj Joshi ${ }^{1,2 *}$ (1), Mohan Rawal ${ }^{3}$ (b)
}

\author{
${ }^{1}$ Manendra Ratna Campus Tahachal, Tribhuvan University, NEPAL \\ ${ }^{2}$ Nepal Open University, NEPAL \\ ${ }^{3}$ Shree Badhi Malika Secondary School Bajura, NEPAL \\ *Corresponding Author: dirgha@nou.edu.np
}

Citation: Joshi, D. R., \& Rawal, M. (2021). Mathematics Teachers Standing on the Utilization of Digital Resources in Kathmandu, Nepal. Contemporary Mathematics and Science Education, 2(1), ep21004. https://doi.org/10.30935/conmaths/9679

\begin{abstract}
The standing of mathematics teachers on the use of digital resources represents the mathematics teaching-related of online resources, mobile applications, and software. The study focused on how mathematics teachers are using digital resources in their classroom practices. The study was carried out among 147 mathematics teachers in Kathmandu Nepal. The finding indicates that digital resources using the level of mathematics teachers were found low. The teaching experience is a contributing factor to the use of online resources whereas teaching level and qualifications are contributing factors of using the software. The finding suggested all stakeholders bargain away out towards the regular and effective application of digital resources in the classroom practice and digital capacity enhancement of teachers.
\end{abstract}

Keywords: Mathematics teaching, digital resources, ICT, software, mobile apps, online resources

Received: 22 Sep. $2020 \bullet$ Accepted: 24 Nov. 2020

\section{INTRODUCTION}

Mathematics is applicable in our regular activities, scientific innovations, research, business, and others. It is a compulsory subject in the school level of Nepal. Different digital resources can be used in mathematics teaching as instructional materials. Varieties of digital resources have developed to support the instructional practices in mathematics. The major digital resources that are used as in instructional practice in mathematics as internet, computer, laptop, mobile, tabs and radio, television (TV). The use of digital resources encourages learners for self-learning, multiway of learning, improvement on logical and critical thinking, communicating skill thereby increasing the mathematical thinking and reasoning of the learners. Such accomplishments enlighten their performance and ultimately enhance their problem-solving ability in the learners which are the consequences of technology-based teaching in mathematics. This study highlights the importance of utilization of digital resources in mathematics and encourage the teachers to the use of such resources.

Digital resources for mathematics teaching represent the online resources that can be used through internet, software indicates the tools which can be used through the computer, laptop and iPads and mobile apps indicates those tools which can run and use in the mobile. After the use and review of several resources, few resources were selected under the study on the basis of (i) freely accessible, (ii) relevant to the school curriculum of mathematics, (iii) applicable to the classroom practices, (iv) curriculum of ICT in Mathematics Education of B. Ed. and M. Ed. of mathematics education in university level (v) developed by Nepalese organizations/institutions, (vi) teacher training, teacher service commission and teaching license curriculum of Nepal, and (vii) TPCK, SAMR and ICT competency model of UNESCO. Agyei and Benning (2015) suggested that teacher should develop their ICT skills for effective teaching and integration of technology in the classroom teaching. So, utilization of digital resources indicates the use of such resources in mathematics teaching. For this study utilization of digital resources by mathematical instructors means how the teachers are using these resources in their instructional practices. Mathematics is a compulsory subject in school education in Nepal. Secondary Education Examination (SEE) of National Examination Board (NEB) shows that the average achievement score of mathematics is below 50 (MOE, 2017). Panthi and Belbase (2017) pointed out that lack of instructional materials and digital resources is one of the major issues in mathematics learning in Nepal.

Information and Communication Technology (ICT) in education is the mode of education that uses ICT to maintain, enhance, and optimize the delivery of information. The different sources of ICT in education include use of mobile, TV, computer, laptop, online resources, software and mobile apps in teaching and learning process. Many research reports show that ICT help to improve the achievement of the students. In the present context ICT related content is integrated into the curriculum of university level and teacher training curriculum of the government. Government and other organizations have great 
financial and technical efforts on digital resources management in the scholastic societies. The present study aims to find out the current status of school teacher towards the consumption of ICT based teaching practices in the schoolroom. ICT related policies of Nepal have several priorities for the technological implication in instructive practices as: Digital Nepal Framework Nepal 2019 focused on smart classroom, online and mobile learning (MoCIT, 2019), school sector development plan (SSDP) 2017-2023 dedicated to promote the ICT skills of students and teachers (MoE, 2016), ICT policy 2015 absorbed on integration of ICT in administration, pedagogy, training, learning and research and developed the concept of e-schools, e-learning and e-education (MoIC, 2015), and ICT in Education Master Plan 2013-3017 engrossed on overall development of modern technology in education like ICT infrastructures, human resources, digital contents and system enhancement (MoE, 2013).

Mathematics instructors were extremely inspired towards the use of technological tools (Dhakal, 2018) in case of Mid-Western University. Technology comforts to accomplish the miscellaneous programs of instructions (Bhattarai, 2019), collaboration and engagement on social, emotional and cognitive aspects on students by virtual learning environment (Dhaka \& Sharma, 2016), positive effect (Dixit, 2009) were found by using ICT in learners insight and educational involvement (Mainali \& Heck, 2017), technology is effective to generate erudition setting (Dhakal \& Pant, 2016) visualize the mathematical concepts (Ozmantar et al., 2009), learners have positive attitude through mobile learning (Parajuli, 2016), it increase the superiority and availability of learning (Noor-Ul-Amin, 2013). ICT assimilated classes upturns the students to adopt with mathematical ideas, processes and resolve the problems (Sivakova et al., 2017).

Numbers of mobile applications have been technologically advanced for the support of learning mathematics (Larkin, 2013). The mobile applications have optimistic impact on students' achievement (Crompton \& Burke, 2015; Etcuban \& Pantinople, 2018; Supandi et al., 2018) and perception of students and teachers' (Celik \& Karayaman, 2018; Skillen, 2015). Mobile learning driven to the learners towards self-learning, amusing learning (Drigas \& Pappas, 2015) and helps to change the learning habits (Supandi et al., 2018) additionally it helps to develop positive attitude, enhance mathematical thinking and develop social and emotional skills of the learners (Al-Takhyneh, 2018). This result shows that mobile applications are highly beneficial for teaching and learning of mathematics even the studies did not focus on particular applications mentioned hear so this will fulfill that gap of research.

Several web portals can be found in the digital platform for the support of learning mathematics. On the basis of accessible issues and curriculum of school level mathematics of Nepal some web-based resources have been selected under the study. These types of resources have positive impression on teachers and students (Zermeno \& Gutierrez, 2018) for mathematics learning (Loong, 2003), upsurge the satisfaction level of students, motivate towards effective and selflearning to the learners (Kartika, 2018). These types of resources are highly potential for meaningful learning (Portela, 2007), understand core mathematical concepts (Kong, Horani, \& Daniel, 2005) and face academic challenges (Geomez-Zermeno \& Franco-Gutierrez, 2018). Mailizar and Fan (2019) have studied the teacher's knowledge on computer hardware, generic software, mathematical software (GeoGebra) and online tools (khan academy and Moodle), and found moderate knowledge.
These results suggest the importance of online resources for mathematics learning. Even those studies had not focused on particular resources like on this study. Status of multiple resources utilization in mathematics teaching related studies were not carried out in national and international context. Government of Nepal have several policies and practices for ICT integration in instructional practices which are mentioned above. Infrastructure and human resources development, internet connectivity, digital literacy, open and distance learning, digital content and assessment and technology-based teacher training are the main concerns of the Nepal (ADB, 2017). This study shows actual status of digital resources utilization in school level mathematics. Additionally, this study was carried out in capital city as well as developed area of Nepal. So, it will be helpful to all stockholders of education for the development and implement new policies. Nepal is developing country and such studies had not carried out in developing countries. Regarding the use of digital devices have several such gaps to be filled by this study. On behaves of several benefits of digital resources utilization in teaching and learning of mathematics this research is relevant, significant and important in present context. In this research, the following research questions were adopted (1) what is the strength of mathematics teachers to use digital resources in classroom teaching? (2) Is there a significant difference in the use of digital resources in relation to school types, gender, teaching level, qualification, age, teaching experience and appointment type of mathematics teacher?

\section{MATERIALS AND METHODS}

The cross-sectional survey design (Patten \& Newhart, 2018) was conducted in the study. Self-constructed tool was implemented. Tool was developed on the basis of literature, ICT in Mathematics curriculum of B. Ed. and M. Ed. level of university level, technological knowledge of Technological, Pedagogical and Content Knowledge (TPCK) (Koh, Chai, \& Lim, 2017), Substitution, Augmentation, Modification and Redefinition (SAMR) (Hamilton, Rosenberg, \& Akcaoglu, 2016) model with pedagogy wheel (Carrington, 2016), two components as application of digital skills and teacher professional learning of UNESCO ICT competency framework of teachers (UNESCO, 2018) and Digital Nepal Framework (MoCIT, 2019). The reliability of the tool is 0.77 which was planned by Cronbach's Alpha technique and for the validation of tool, content validity was intended by providing tool to related subject experts.

\section{Study Setting and Sampling}

The total number of schools in Kathmandu district are 1362 (GON, 2017) even record of the total number of mathematics teachers and the number of schools having computer facilities were not found in District Education Office Kathmandu. So the study includes 147 secondary level teachers from 50 schools of Kathmandu by theoretical sampling (Coolican, 2013) technique from Feb. to May 2019.

\section{Data Collection}

Data were collected by visiting the schools. The self-constructed tool was given to the mathematics teachers by taking permission of school principals and requested the related teachers to fill-up the questionnaire. 


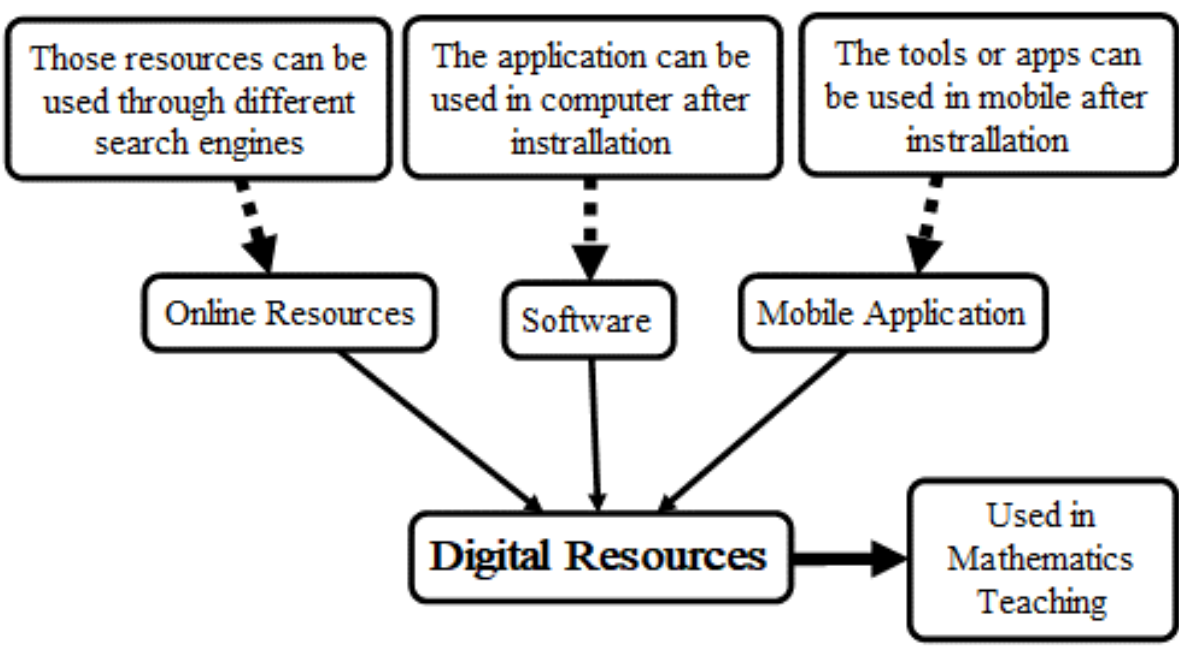

Figure 1. Conceptual framework

\section{Definition of Variables}

Types of school, Gender, Teaching Level, Qualification, Age, Experience and Appointment types were taken as socio-demographic variables. Types of schools were characterized in private and public as per the rule of the government of Nepal. Level of teaching has considered in three fragments as primary (teaching up to 5 classes), lower secondary (teaching in 6-8 classes) and secondary (teaching in class 9-10 classes) even that level is newly defined as basic (1-8 classes) and secondary level (9-12 classes) by the government. On the basis of age of the respondent it has categorized as 20 to 40 years and 41 to 60 years, similarly experience as $\leq 10$ years and $>10$ years. The appointment type has categorized as permanent and temporary as per the rule of government and institutes.

The consequence variables are characterized under three-domain as online resources, software and mobile apps. All the resources have been taken on the basis of sustenance to the content under the domestic prospectus of the school level of Nepal. There are the numbers of resources for the support of teaching and learning of mathematics even limited resources have been taken under the study. Researchers searched verities of sources supportive of mathematics learning for school students and mentioned more useful applications. Online resources are those which are available in the form of audio, video, audio-visual and text documents supportive to the teachers and students and can be used in the browser with an internet connection. Under software some popular, useful and those included in B. Ed. and M.Ed. the curriculum of mathematics education was selected. In mobile apps, some freely available, applicable and easily accessible resources have been taken.

\section{Statistical Analysis}

Descriptive and inferential statistics have been implemented under the study. Mean, variance and covariance were calculated under the descriptive statistics for the status of utilization of digital resources. Digital resource using level were determined like1-2.34 is low, 2.343.67 is medium and 3.7-5 is high level based on the mean value of each items (Alharbi, 2014). Mann Whitney U test and Kruskal-Wallis H were calculated under inferential statistics for the reason that no randomness on sampling and abnormal distribution of data (normality was tested on the $5 \%$ level of significant by Shapiro-Wilk and Kolmogorov-Smirnov tests (Sá, 2007) where $\mathrm{p}<0.05$ in all cases) for
Table 1. Socio-demographic characteristics $(n=147)$

\begin{tabular}{|c|c|c|}
\hline Variables & Frequency & Percentage \\
\hline \multicolumn{3}{|l|}{ Types of school } \\
\hline Public & 43 & 29.3 \\
\hline Private & 104 & 70.7 \\
\hline \multicolumn{3}{|l|}{ Gender } \\
\hline Male & 109 & 74.1 \\
\hline Female & 38 & 25.9 \\
\hline \multicolumn{3}{|l|}{ Teaching Level } \\
\hline Primary & 30 & 20.4 \\
\hline Lower Secondary & 27 & 18.4 \\
\hline Secondary & 90 & 61.2 \\
\hline \multicolumn{3}{|l|}{ Qualification } \\
\hline Intermediate & 12 & 8.2 \\
\hline Bachelor & 65 & 44.2 \\
\hline Master & 70 & 47.6 \\
\hline \multicolumn{3}{|l|}{ Age } \\
\hline 20 to 40 years & 127 & 86.4 \\
\hline 41 to 60 years & 20 & 13.6 \\
\hline \multicolumn{3}{|l|}{ Experience } \\
\hline$\leq 10$ years & 116 & 78.9 \\
\hline$>10$ years & 31 & 21.1 \\
\hline \multicolumn{3}{|l|}{ Appointment types } \\
\hline Permanent & 55 & 37.4 \\
\hline Temporary & 92 & 62.6 \\
\hline
\end{tabular}

testing the significant result at $95 \%$ confidence level between two and more than two independent samples respectively (Cohen, Manion, \& Morrison, 2007). These inferential statics were calculated based on the sum of rating scores of online resources, software and mobile apps. The $\mathrm{p}$-value $\leq 0.05$ was considered as statistically significant and data were analyzed by using Statistical Package for Social Science (SPSS version 23 for window).

\section{RESULTS}

Table 1 showed the detail of socio-demographic characteristics. Around two-third of the participants were from private (70.7\%), male (74.1\%), secondary level (61.2\%) and temporary teachers (62.6\%). Majority of the teachers belonging to $20-40$ years (86.4\%) and having 


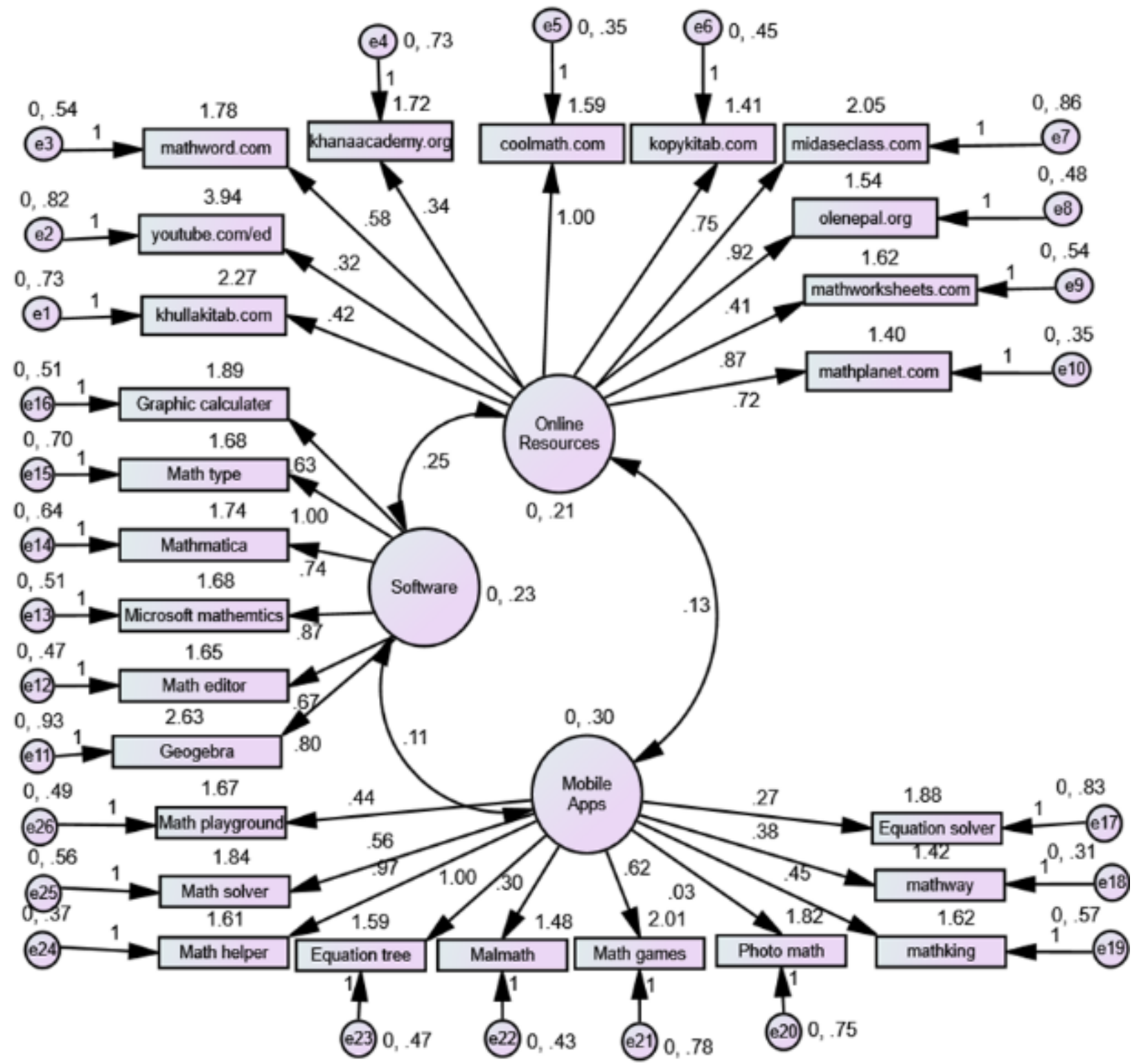

Figure 2. Status of the use of digital resources

teaching experience less or equal to 10 years $(78.9 \%)$ and around half of the respondent $(47.6 \%)$ have qualification master degree.

Figure 2 shows that online resources using levels were found to be low in all items except as use of YouTube $\left(\bar{x}=3.94, \sigma^{2}=0.92\right)$ under online resources. After that khullakitab.com $\left(\bar{x}=2.77, \sigma^{2}=0.73\right)$ and midaseclass.com ( $\left.\bar{x}=2.05, \sigma^{2}=0.86\right)$ have some practices in using classroom practices. Under software categories, the software using level found to be low in each case except as GeoGebra $\left(\bar{x}=2.63, \sigma^{2}=0.93\right)$. Additionally, it can be seen that very few numbers of teachers are using mobile apps in their teaching and learning activities because of the mean of each items under mobile application is between 1.42 (Mathway) to 2.04 (Math Game) which belongs to low categories.

Table 2 shows that significant results was measured in online resources with respect to experience in favor of $>10$ years' experience, similar result were found in software with respect to teaching level and qualification in favor of high level (secondary) and high qualifications (master) teachers. The Mann Whitney U and Kruskal Wallis $\mathrm{H}$ tests shows insignificant results in remaining cases at 95\% level of confidence. Also, from the same table it can be seen that online resources are poorly used by the mathematics teachers having intermediate $(\bar{x}=1.83, \mathrm{SD}=0.14)$ and bachelor $(\bar{x}=1.88, \mathrm{SD}=0.29)$ qualification whereas that rate is comparatively good in $>10$ years' experience teachers ( $\bar{x}=2.07, \mathrm{SD}=0.49)$. The use of software found to be very poor by primary level teachers $(\bar{x}=1 / 60, \mathrm{SD}=0.24)$ and those teachers having intermediate qualification $(\bar{x}=1.53, \mathrm{SD}=0.21)$ whereas the use of mobile found to be poor among the teachers having age $>40$ years $(\bar{x}=1.62, \mathrm{SD}=0.25)$.

\section{DISCUSSION}

Digital resources were categorized in three categories as online resources mobile app, software and online resources. Online resources using levels were found to be low in all items except as use of YouTube it may cause that YouTube is commonly used application for different purpose. Secondly, khullakitab.com and midaseclass.com also have some use then others which may cause that these resources have been developed based on the school curriculum of Nepal besides this the teachers are not using other resources hence the teacher have very poor knowledge of online resources developed by different stakeholders. Loong (2003) found that 20 to $90 \%$ number of mathematics teachers 
Table 2. Significant result of the use of online resources, software and mobile apps with socio-demographic variables $(\mathrm{n}=147)$

\begin{tabular}{|c|c|c|c|c|c|c|}
\hline \multirow[t]{2}{*}{ Variables (\%) } & \multicolumn{2}{|c|}{ Online resources } & \multicolumn{2}{|c|}{ Software } & \multicolumn{2}{|c|}{ Mobile App } \\
\hline & Mean, SD & p-value & Mean, SD & p-value & Mean, SD & p-value \\
\hline \multicolumn{7}{|l|}{ Types of school } \\
\hline Public (29.3) & $1.96,0.42$ & 0.48 & $1.86,0.48$ & 0.74 & $1.65,0.37$ & 0.22 \\
\hline Private $(70.7)$ & $1.92,0.39$ & & $1.89,0.51$ & & $1.72,0.35$ & \\
\hline \multicolumn{7}{|l|}{ Gender } \\
\hline Male (74.1) & $1.95,0.40$ & 0.42 & $1.92,0.53$ & 0.13 & $1.69,0.38$ & 0.36 \\
\hline Female (25.9) & $1.88,0.38$ & & $1.76,0.39$ & & $1.70,0.28$ & \\
\hline \multicolumn{7}{|l|}{ Teaching Level } \\
\hline Primary (20.4) & $1.90,0.19$ & 0.35 & $1.60,0.24$ & $0.00^{*}$ & $1.61,0.23$ & 0.57 \\
\hline Lower Secondary (18.4) & $1.93,0.23$ & & $1.75,0.23$ & & $1.68,0.20$ & \\
\hline Secondary (61.2) & $1.95,0.48$ & & $2.01,0.57$ & & $1.73,0.42$ & \\
\hline \multicolumn{7}{|l|}{ Qualification } \\
\hline Intermediate (8.2) & $1.83,0.14$ & 0.82 & $1.53,0.21$ & $0.00^{*}$ & $1.63,0.17$ & 0.36 \\
\hline Bachelor (44.2) & $1.88,0.29$ & & $1.80,0.40$ & & $1.63,0.26$ & \\
\hline Master (47.6) & $2.00,0.49$ & & $2.01,0.57$ & & $1.77,0.44$ & \\
\hline \multicolumn{7}{|l|}{ Age } \\
\hline 20 to 40 years $(86.4)$ & $1.91,0.36$ & 0.15 & $1.86,0.49$ & 0.19 & $1.71,0.37$ & 0.48 \\
\hline 41 to 60 years (13.6) & $2.07,0.54$ & & $2.01,0.58$ & & $1.62,0.25$ & \\
\hline \multicolumn{7}{|l|}{ Experience } \\
\hline$\leq 10$ years $(78.9)$ & $1.90,0.36$ & $0.03^{*}$ & $1.86,0.50$ & 0.13 & $1.71,0.38$ & 0.67 \\
\hline$>10$ years $(21.1)$ & $2.07,0.49$ & & $1.94,0.50$ & & $1.65,0.27$ & \\
\hline \multicolumn{7}{|l|}{ Appointment types } \\
\hline Permanent (37.4) & $1.94,0.44$ & 0.77 & $1.86,0.46$ & 0.87 & $1.69,0.36$ & 0.86 \\
\hline Temporary (62.6) & $1.93,0.37$ & & $1.89,0.53$ & & $1.70,0,36$ & \\
\hline
\end{tabular}

${ }^{*} \mathrm{p}$-value $\leq 0.05$ (i.e. significant)

used different web resources for preparation and presentation in Australia which indicates that the country has good practices of internet usage in mathematics teaching and the country is in developed categories however this study was conducted in developing country. In case of software, the teachers are using GeoGebra in comparison to others which may cause that this software is a part of the curriculum of ICT in Mathematics Education at bachelor and master level. The result of the study also showed that mathematics teachers of Nepal have a very low practice of exhausting mobile apps. Where Etcuban and Pantinople (2018) found that mobile applications are constructive for erudition to the learners, and Celik and Karayaman (2018) found positive replies of perspective teachers towards mobile learning. Crompton and Burke (2015) reported that mobile applications are relevant in mathematics learning at primary level. Level of attitude of the students towards the use of mobile applications were found to be high in Jordan (AlTakhyneh, 2018). In Malesia, Kong et al. (2005) found that only 5.4\% teachers were frequently using ICT tools in their instructional practices and $21.6 \%$ of them used ICT in particular contents which is in favor of the result of this study even that study was before 15 years.

The significant results were measured in online resources with respect to experience in favor of $>10$ years' experience, in software with respect to teaching level and qualification in favor of high level (secondary) and high qualifications (master) teachers whereas the result found to be insignificant in remaining cases at $95 \%$ level of confidence. Online resources are poorly used by the mathematics teachers having intermediate and bachelor qualification, use of software found to be very poor by primary level teachers and those teachers having intermediate qualification whereas the use of mobile found to be poor among the teachers having age $>40$. In case of attitude of male and female perspective teachers to mobile learning, Celik and Karayaman (2018) found significant result in errand of male teacher. Al-Takhyneh (2018) found insignificant result in the use of mobile apps between science and humanity stream students in addition to employed and nonemployed students in Jordan. Overall results show that the strength of mathematics teachers in the use of digital resources found to be poor in almost cases. Similar result was found by Mailizar and Fan (2019) in Indonesia, Amuko (2015) in Kenya, and Agyei and Voogt (2011) in Ghana. In case technological knowledge similar results were found in Tanzania among perspective teachers (Kihoza et al., 2016). However, the result of this study is limited to only 147 mathematics teachers hence it is limited to generalized other situations. In the comparison to ICT competency model of UNESCO, mathematics teachers of Nepal are under the digital literacy phase, few of the teachers have technological knowledge and almost teachers are found to be under the substitution and augmentation phase of the SAMR model.

\section{CONCLUSION}

From all of the above results, it is clear that digital resources using levels of mathematics teachers found to be unfortunate. Experience of teacher is contributing factor of the use of online resources and teaching level and qualifications are contributing factors of using software. On the basis of these results, it can be said that the mathematics teachers of the school level of Nepal are poorly familiar with 21st-century digital resources. The study was carried out in the capital city of Nepal which is comparably advanced in the sense of different indicators. This result, as seen in developed places like the capital of Nepal, can easily be predicted the situation of other remote places of Nepal. The study helps mathematics teachers to introduce different digital resources and significant of their usages as well as national and international standards of 21 st-century skills. The study is limited to sample size, mathematics teachers and Kathmandu Nepal only hence the result of this research will not be generalized in other settings so further research can be 
carried out to find the answer to why mathematics teachers are not properly using such resources in classroom practices. On the behave of the finding of this research, it can be recommended that the government and other stakeholders should focus on the classroom practices of the use of digital resources and should design and implement the robust tactics for teachers' digital resources utilization skills enhancement program.

\section{ACKNOWLEDGEMENT}

We thank all the mathematics teachers of Kathmandu Nepal who participated in this study.

\section{REFERENCES}

ADB. (2017). Innovative Strategies for Accelerated Human Resource Innovative Strategies for Accelerated Human Resource Development in South Asia: Nepal. Asian Development Bank. http://hdl.handle.net/11540/5260

Agyei, D. D., \& Benning, I. (2015). Pre- Service Teachers' Use and Perceptions of Geogebra Software as an Instructional Tool in Teaching Mathematics. Journal of Educational Development and Practice, 5(1), 14-30. https://doi.org/10.3844/jmssp.2012.253.257

Agyei, D. D., \& Voogt, J. (2011). ICT use in the teaching of mathematics: Implications for professional development of preservice teachers in Ghana. Education and Information Technologies, 16, 423-439. https://doi.org/10.1007/s10639-010-9141-9

Alharbi, E. (2014). A Study on the Use of ICT in Teaching in Secondary Schools in Kuwait. Cardiff Metropolitan University, Kuwait. Retrieved from https://repository.cardiffmet.ac.uk/handle/10369/ 5675

Al-Takhyneh, B. (2018). Attitudes towards Using Mobile Applications in Teaching Mathematics in Open Learning Systems. International Journal of E-Learning \& Distance Education, 33(1), 1-16. Retrieved from https://files.eric.ed.gov/fulltext/EJ1180063.pdf

Amuko, S. (2015). Pedagogical Practicesin Integrationof ICT in Teaching and Learning Mathematics, in Secondary Schools in Nairobi County, Kenya. IOSR Journal of Mathematics, 11(5), 20-23. https://doi.org/10.9790/5728-11512023

Bhattarai, L. N. (2019). ICT Integrated Pedagogy in a Multicultural Classroom: Experiences of Mathematics Teacher. Interdisciplinary Research in Education, 4(1), 9-18. https://doi.org/10.3126/ire.v4i1. 25706

Carrington, A. (2016). The Padagogy Wheel ENG V5.0 Android Retrieved from https://designingoutcomes.com/assets/PadWheel V5/PW_ENG_V5.0_Android_PRINT.pdf

Celik, H. C., \& Karayaman, S. (2018). Investigating Attitudes of Prospective Mathematics Teachers towards the Use of Mobile Learning at a Higher Learning Institution. Universal Journal of Educational Research, 6(8), 1784-1794. https://doi.org/10.13189/ ujer.2018.060823

Cohen, L., Manion, L., \& Morrison, K. (2007). Research Methods in Education (6th ed.). London and New York: Routledge. https://doi.org/10.4324/9780203029053
Coolican, H. (2013). Research Methods and Statistics in Psychology (2nd ed.). London and New York: Routledge. https://doi.org/10.4324/9780203769669

Crompton, H., \& Burke, D. (2015). Research Trends in the Use of Mobile Learning in Mathematics. International Journal of Mobile and Blended Learning, 7(4), 1-15. https://doi.org/10.4018/IJMBL. 2015100101

Dhaka, B. P., \& Sharma, L. (2016). Virtual Learning Environment (VLE) in Mathematics Education. Education Journal, 5(6), 126-135. https://doi.org/10.11648/j.edu.20160506.11

Dhakal, P. K. (2018). Use of ICT tools in teaching mathematics in higher education: A case of mid-Western University. International Journal of Multidisciplinary Perspectives in Higher Education, 3(1), 8188. https://doi.org/10.32674/jimphe.v3i1.636

Dhakal, R. K., \& Pant, B. P. (2016). Assessment of teacher education curricula in Nepal: An ICT perspective. International Journal of Innovation, Creativity and Change, 2(3), 96-107. Retrieved from https://www.ijicc.net/images/Vol2iss3/2Teacher_Ed_and_Nepal_ May_2016.pdf

Dixit, U. (2009). The use of ICT in teacher training: Nepal's experience. International Conference on Education and World Bank-KERIS High Level Seminar on ICT in Education. Retrieved from http://citeseerx.ist.psu.edu/viewdoc/download?doi=10.1.1.535.93 $2 \&$ rep $=$ rep $1 \&$ type $=$ pdf

Drigas, A. S., \& Pappas, M. A. (2015). A Review of Mobile Learning Applications for Mathematics. International Journal of Interactive Mobile Technologies, 9(3), 18-23. https://doi.org/10.3991/ ijim.v9i3.4420

Etcuban, J. O., \& Pantinople, L. D. (2018). The Effects of Mobile Application in Teaching High School Mathematics. International Electronic Journal of Mathematics Education, 13(3), 249-259. https://doi.org/10.12973/iejme/3906

Geomez-Zermeno, M., \& Franco-Gutierrez, H. (2018). The Use of Educational Platforms as Teaching Resource in Mathematics. Journal of Technology and Science Education, 8(1), 63-71. https://doi.org/10.3926/jotse.337

GON. (2017). Education in Figures 2016 at - a - Glance. Ministry of Education, Science \& Technology.

Hamilton, E. R., Rosenberg, J. M., \& Akcaoglu, M. (2016). The Substitution Augmentation Modification Redefinition (SAMR) Model: A Critical Review and Suggestions for its Use. TechTrends Springer, 60(5), 433-441. https://doi.org/10.1007/s11528-0160091-y

Kartika, H. (2018). Teaching and Learning Mathematics Through Web-Based Resource: An Interactive Approach. MaPan: Jurnal Matematika Dan Pembelajaran, 6(1), 1-10. https://doi.org/10.24252/ mapan.2018v6n1a1

Kihoza, P., Zlotnikova, I., Bada, J., \& Kalegele, K. (2016). Classroom ICT integration in Tanzania: Opportunities and challenges from the perspectives of TPACK and SAMR models. International Journal of Education and Development Using Information and Communication Technology (IJEDICT), 12(1), 107-128. Retrieved from https://files.eric.ed.gov/fulltext/EJ1099588.pdf 
Koh, J. H. L., Chai, C. S., \& Lim, W. Y. (2017). Teacher Professional Development for TPACK-21CL: Effects on Teacher ICT Integration and Student Outcomes. Journal of Educational Computing Research, 55(2), 172-196. https://doi.org/10.1177/07356331166 56848

Kong, C. C., Horani, S., \& Daniel, J. (2005). A Study on the Use of ICT in Mathematics Teaching. Malaysian Online Journal of Instructional Technology (MOJIT), 2(3), 43-51. Retrieved from https://pdfs.semanticscholar.org/0419/ba0310ac083bdb277238c5 $800 \mathrm{a} 059 \mathrm{ccd} 142 \mathrm{c}$.pdf

Larkin, K. (2013). Mathematics Education: Is There an App For That? In Mathematics Education: Yesterday, today and tomorrow (Proceedings of the 36th annual conference of the Mathematics Education Research Group of Australia) (pp. 1-8). Retrieved from https://files.eric.ed.gov/fulltext/ED572942.pdf

Loong, E. (2003). Australian Secondary School Teachers' Use of the Internet for Mathematics. In 26th Conference of the Mathematics Education Research Group of Australasia (pp. 484-491). Retrieved from https://pdfs.semanticscholar.org/5fcb/33c4f7326fb9c241f82 66c3792dda21e96ce.pdf

Mailizar, M., \& Fan, L. (2019). Indonesian Teachers' Knowledge of ICT and the Use of ICT in Secondary Mathematics Teaching. Eurasia Journal of Mathematics, Science and Technology Education, 16(1), em1799. https://doi.org/10.29333/ejmste/110352

Mainali, B. R., \& Heck, A. (2017). Comparison of Traditional Instruction on Reflection and Rotation in a Nepalese High School with an ICT-Rich, Student-Centered, Investigative Approach. International Journal of Science and Mathematics Education, 15(3), 487507. https://doi.org/10.1007/s10763-015-9701-y

MoCIT. (2019). 2019 Digital Nepal Framework. Ministry of Communication and Information Technology. Nepal.

MoE. (2013). Information \& Communication Technology (ICT) in Education Master Plan 2013-2017. Ministry of Education Nepal.

MoE. (2016). School Sector Development Plan 2016-2023. Ministry of Education, Nepal.

MoIC. (2015). National Information and Communication Technology Policy, 2015. Ministry of Information and Communication, Nepal.

Noor-Ul-Amin, S. (2013). An Effective use of ICT for Education and Learning by Drawing on Worldwide Knowledge, Research, and Experience: ICT as a Change Agent for Education. Scholarly Journal of Education, 2(4), 38-45. Retrieved from http://scholarlyjournals.com/sje/archive/2013/April/pdf/Noor-Ul-Amin.pdf
Ozmantar, M. F., Akkoc, H., Bingolbali, E., Demir, S., \& Ergene, B. (2009). Pre-service mathematics teachers' use of multiple representations in technology-rich environments. Eurasia Journal of Mathematics, Science and Technology Education, 6(1), 19-37. https://doi.org/10.12973/ejmste/75224

Panthi, R. K., \& Belbase, S. (2017). Teaching and Learning Issues in Mathematics in the Context of Nepal. European Journal of Educational and Social Sciences, 2(1), 1-27. https://doi.org/10.20944/preprints201706.0029.v1

Parajuli, K. P. (2016). Mobile Learning Practice in Higher Education in Nepal. Open Praxis, 8(1), 41-54. https://doi.org/10.5944/ openpraxis.8.1.245

Patten, M. L., \& Newhart, M. (2018). Understanding Research Methods: An Overview of the Essentials (10th ed.). London and New York: Routledge. https://doi.org/10.4324/9781315213033

Portela, J. (2007). Communicating Mathematics Through the Internet: A Case Study. Interactive Educational Multimedia, 14, 65-78. Retrieved from http://ipvc.academia.edu/Jos?Portela/Papers/ 355906/Communicating_Mathematics_Through_the_InternetA_Case_Study

Sá, J. P. M. de. (2007). Applied Statistics Using SPSS, STATISTICA, $M A T L A B$ and $R$ (2nd ed.). Berlin, Heidelberg, and New York: Springer.

Sivakova, D., Kochoska, J., Ristevska, M., \& Gramatkovski, B. (2017). ICT - The Educational Programs in Teaching Mathematics. TEM Journal, 6(3), 469-478. https://doi.org/10.18421/TEM63-06

Skillen, M. A. (2015). Mobile Learning: Impacts on Mathematics Education. In Proceedings of the 20th Asian Technology Conference in Mathematics (Leshan, China, 2015) Mobile (pp. 205-214). Retrieved from http://atcm.mathandtech.org/EP2015/full/3.pdf

Supandi, Ariyanto, L., Kusumaningsih, W., \& Aini, A. N. (2018). Mobile phone application for mathematics learning. Journal of Physics: Conference Series, 983, 012106. https://doi.org/10.1088/ 1742-6596/983/1/012106

UNESCO. (2018). UNESCO ICT Competency Framework for Teachers / OER Commons. United Nations Educational, Scientific and Cultural Organization, France. France. Retrieved from https://www.open. edu/openlearncreate/pluginfile.php/306820/mod_resource/conte nt/2/UNESCO ICT Competency Framework V3.pdf

Zermeno, M. G., \& Gutierrez, H. F. (2018). Journal of technology and science education. Journal of Technology and Science Education, 8(1), 63-71. https://doi.org/10.3926/jotse.337 